\title{
2017 APSA Organized Section Awards Presented
}

$\mathrm{I}$ $\mathrm{n}$ addition to the APSA awards (see full listing and citations in the Gazette Lin this issue as well as pictures under APSA Awards in this section), the following recognitions were announced by the APSA Organized Sections.

\section{SECTION 01. FEDERALISM \& INTER-} GOVERNMENTAL RELATIONS

\section{Martha Derthick Book Award}

The Martha Derthick Book Award is conferred for the best book published at least 10 years ago that has made a lasting contribution to the study of federalism and intergovernmental relations.

Award Committee: Saundra Schneider, Chair, Michigan State University; Philip Rocco, Marquette University; Sonja Walti, American University

Recipient: Barry G. Rabe, University of Michigan

Title: Statehouse and Greenhouse: The Emerging Politics of American Climate Change Policy. Brookings Institution Press, 2004 .

\section{Daniel Elazar Distinguished Federal- ism Scholar Award}

The Daniel Elazar Distinguished Federalism Scholar Award recognizes distinguished scholarly contributions to the study of federalism and intergovernmental relations.

Award Committee: Paul Manna, Chair, College of William and Mary; Ann Bowman, Texas A\&M University; Jennifer Wallner, University of Ottawa

Recipient: Liesbet Hooghe, University of North Carolina at Chapel Hill

Recipient: Gary Marks, University of North Carolina at Chapel Hill

\section{Deil S. Wright Best Paper Award}

The Deil S. Wright Best Paper Award is conferred for the best paper in the field of federalism and intergovernmental relations presented at the previous year's annual meeting of the APSA.

Award Committee: Jennifer Wolak, Chair, University of Colorado; Maria EscobarLemmon, Texas A\&M University; Lisa Miller, Rutgers University

Recipients: Fabrizio Gilardi, University of Zurich;Charles R. Shipan, University of Michigan; Bruno Wueest, University of Zurich
Title: "The Diffusion of Policy Frames: Evidence from a Structural Topics Model."

\section{John Kincaid Best Article Award}

The John Kincaid Best Article Award is conferred on the author(s) of the best article published in Publius: The Journal of Federalism in the previous year.

Award Committee: Charles Hankla, Chair, Georgia State University; Claudia Avellaneda, Indiana University; Adam Myers, Providence College

Recipient: Jason P. Sorens, Dartmouth College

Title: "Secession Risk and Fiscal Federalism." 2016. Publius: The Journal of Federalism 46(1): 25-50.

\section{SECTION 02. LAW AND COURTS}

\section{Best Graduate Student Paper Award}

The Best Graduate Student Paper Award is given annually for the best paper on law and courts written by a graduate student.

Award Committee: Pam Corley, Chair, Southern Methodist University; Joe Ura, Texas A\&M University; Laura Moyer, University of Louisville; Maron Sorenson, Bowdoin College; Eric Kasper, University of Wisconsin, Eau Claire

Recipients: David Gelman and Doug Johnson, University of Rochester

Title: "The Beliefs and Behavior of Appellate Court Judges."

Honorable Mention: Natalie Rogol, Matthew Montgomery, and Justin Kingsland, Georgia State University

Title: "Going Public: Presidential Impact on Supreme Court Decision-Making."

\section{Teaching and Mentoring Award}

The Teaching and Mentoring Award recognizes innovative teaching and instructional methods and materials in law and courts. Examples of innovations that might be recognized by this award include (but are not limited to) outstanding textbooks, websites, classroom exercises, syllabi, or other devices designed to enhance the transmission of knowledge about law and courts to undergraduate or graduate students.

Award Committee: Kirk Randazzo, Chair, University of South Carolina; Quinn Mulroy, Northwestern University; Joseph Smith, University of Alabama; Rachel
Caufield, Drake University; Rachel Ellett, Beloit College

Recipient: H. W. Perry, University of Texas at Austin

\section{Lasting Contribution Award}

The Lasting Contribution Award is given annually for a book or journal article, 10 years or older, that has made a lasting impression on the field of law and courts. Award Committee: Eve Ringsmuth, Chair, Oklahoma State University; Jennifer Bowie, University of Richmond; Kevin Quinn, University of California, Berkeley; Susanee Schorpp, Georgia State University; Mark Richards, Grand Valley State University Recipients: Forrest Maltzman, George Washington University; James F. Spriggs II, Washington University in St. Louis; Paul J. Wahlbeck, George Washington University

Title: Crafting Law on the Supreme Court: The Collegial Game. Cambridge University Press, 2000.

\section{Lifetime Achievement Award}

The Lifetime Achievement Award is an award for a lifetime of significant scholarship, teaching, and service to the law and courts field.

Award Committee: Jennifer Diascro, Chair, University of California; Ryan Owens, University of Wisconsin; Virginia Hettinger, University of Connecticut; Justin Wedeking, University of Kentucky; Kevin McGuire, University of North Carolina at Chapel Hill

Recipient: Doris Maria Provine, Arizona State University

\section{Best Conference Paper Award}

The Law and Courts Best Conference Paper Award (formerly the American Judicature Society Award) is given annually for the best paper on law and courts presented at the previous year's annual meetings of the American, international, or regional political science associations. Single and coauthored papers, written by political scientists, are eligible. Papers may be nominated by any member of the section.

Award Committee: Amy Steigerwalt, Chair, Georgia State University; Patrick Schmidt, Macalester College; Teen Wilhelm, University of Georgia; Mike Nelson, Pennsylvania State University; Rebecca Gill, University of Nevada, Las Vegas 
Recipient: Jonathan Kastellec, Princeton University

Title: "Judicial Federalism and Representation."

Honorable Mention: Deborah Beim, Yale University; Tom S. Clark, Emory University; John W. Patty, University of Chicago Title: "Sequential Adjudication."

\section{Best Journal Article Award}

The Best Journal Article Award recognizes the best journal article on law and courts written by a political scientist and published during the previous calendar year.

Award Committee: Christina Boyd, Chair, University of Georgia; Rachel Hinkle, University of Buffalo; Tom Hansford, University of California, Merced; Scott Comparato, Southern Illinois University; Matt Hitt, Northern Colorado University Recipients: Ryan Black, Michigan State University and Ryan Owens, University of Wisconsin

Title: "Courting the President: How Circuit Court Judges Alter Their Behavior for Promotion to the Supreme Court." The American Journal of Political Science 6o: 30-45.

Honorable Mention:Jay Krehbiel, Washington University in St. Louis

Title: "The Politics of Judicial Procedures: The Role of Public Oral Hearings in the German Constitutional Court." The American Journal of Political Science 60: 990-1005. Honorable Mention: Charles Cameron and Jonathan Kastellec, Princeton University Title: "Are Supreme Court Nominations a Move-the-Median Game?" American Political Science Review 110: 778-97.

Honorable Mention: Deborah Beim, Yale University; Alexander Hirsch, California Institute of Technology; Jonathan Kastellec, Princeton University

Title: "Signaling and Counter-Signaling in the Judicial Hierarchy: An Empirical Analysis of En Banc Review." The American Journal of Political Science 6o: 490-508.

\section{Law and Courts Service Award}

The Law and Courts Service Award recognizes service to the section in the literal sense, as in service on committees and in leadership positions, as well as service within the section, as in service to the profession within the field of law and courts in the form of archiving data, promoting infrastructure, representing the profession in the media, etc.

Award Committee: Wendy Martinek, Binghamton University, SUNY; Gbemende Johnson, Hamilton College; Mike Zilis,
University of Kentucky; Alicia Uribe, University of Illinois; Matt Hall, University of Notre Dame

Recipient: David Klein, Eastern Michigan University

\section{Herman Pritchett Award for Best Book in Law and Courts}

The C. Herman Pritchett Award is given annually for the best book on law and courts written by a political scientist and published the previous year (2016).

Award Committee: Susan Haire, University of Georgia; Alyz Mark, North Central College; Paul Nolette, Marquette University Bethany Blackstone, University of North Texas; Rachel Schutte, Michigan State University

Recipient: Ezequiel A. Gonzales-Ocantos, University of Oxford

Title: Shifting Legal Visions: Judicial Change and Human Rights Trials in Latin America. Cambridge University Press, 2016.

Honorable Mention: Lauren Edelman, University of California, Berkeley

Title: Working Law: Courts, Corporations, and Symbolic Civil Rights. University of Chicago Press, 2016.

\section{SECTION 03. LEGISLATIVE STUDIES}

\section{Richard F. Fenno Prize}

In the tradition of Professor Fenno's work, this prize is designed to honor work that is both theoretically and empirically strong. Moreover, this prize is dedicated to encouraging scholars to pursue new and different avenues of research in order to find answers to previously unexplored questions about the nature of politics.

Award Committee: Sven-Oliver Proksch, University of Cologne, Charles Finocchiaro, University of South Carolina; Nancy Martorano Miller, University of Dayton

Recipients: Douglas L. Kriner, Brown University and Eric Schickler, University of California, Berkeley

Title: Investigating the President: Congressional Checks on Presidential Power. Princeton University Press, 2016.

\section{Carl Albert Dissertation Award}

The Carl Albert Dissertation Award is given annually for the best dissertation in legislative studies. Topics may be national or subnational in focus on the topic of Congress, parliaments, state legislatures, or other representative bodies.
Award Committee: Molly Reynolds, Chair, Brookings Institution; Tiffany Barnes, University of Kentucky; Jonathan Winburn, University of Mississippi

Recipient: Michelle Whyman, Duke University

Title: "The Roots of Legislative Durability: How Information, Deliberation, and Compromise Create Laws that Last." University of Texas at Austin

\section{Jewell-Loewenberg Award}

The Jewell-Loewenberg Award recognizes the best article in the Legislative Studies Quarterly in the previous year.

Award Committee: Anand Edward Sokhey, Chair, University of Colorado at Boulder Jeff Harden, University of Notre Dame; Josh Ryan, Utah State University

Recipients: Douglas Ahler, Jack Citrin, and Gabriel Lenz, University of California, Berkeley

Title: "Do Open Primaries Improve Representation? An Experimental Test of California's 2012 Top-Two Primary." Legislative Studies Quarterly 41 (2): 237-68.

\section{Alan Rosenthal Prize}

In the spirit of Alan Rosenthal's work, this prize is dedicated to encouraging young scholars to study questions that are of importance to legislators and legislative staff and to conduct research that has the potential application to strengthening the practice of representative democracy.

Award Committee: James Curry, Chair, University of Utah; James Battista, University at Buffalo; Eleanor Powell, University of Wisconsin, Madison

Recipient: Tiffany D. Barnes, University of Kentucky

Title: Gendering Legislative Behavior. Cambridge University Press, 2016.

SECTION 04. PUBLIC POLICY

\section{Aaron Wildavsky Enduring Contribu- tion Award}

The Aaron Wildavsky Enduring Contribution Award is given for the best book or article published in the general area of public policy during the past 20-plus years. Award Committee: Kristin Goss, Chair, Duke University; Philippe Zittoun, LET-ENTPE, University of Lyon, France; Mark Peterson, University of California, Los Angeles Recipient: Frank Fischer, Rutgers University Title: Reframing Public Policy. Oxford University Press, 2003. 
Best Comparative Policy Paper Award (with JCPA)

The Best Comparative Policy Paper Award is given to a scholar who has received his or her PhD within the last five years and whose career to date demonstrates unusual promise.

Award Committee: Julia Lynch, Chair, University of Pennsylvania; Jose Luis Mendez, El Colegio de Mexico; Karen Jusko, Stanford University; Klaus Schubert, University of Muenster; Jacint Jordana Casajuana, Universitat Pompeu Fabra

Recipients: Melani Cammett, Harvard University and Aytuğ Şaşmaz, Brown University

Title: "Political Context, Organizational Mission, and the Quality of Social Services: Insights from the Health Sector in Lebanon."

\section{Best Poster on Public Policy Award}

The Best Poster on Public Policy Award is given for the best paper or poster presented at the poster session at the previous APSA Annual Meeting.

Award Committee: Alice Sardell, Chair, Queens College, CUNY; Juliet Gainsborough, Bentley University; Miriam Laguesen, Columbia University; Cynthia Kaplan, University of California, Santa Barbara Recipients: Andrew Kelly, Johns Hopkins University and Philip Rocco, Marquette University

Title: "The Politics of Trial and Error: Medicare Demonstrations and Policy Change."

Recipients: Delphia Shanks-Booth and Mallory SoRelle, Cornell University

Title: "Information v. Ideology: Recognizing (Government) Benefits in the Submerged State."

\section{Best Paper on Public Policy Award}

The Best Paper on Public Policy Award recognizes the best paper on public policy given at the previous APSA Annual Meeting.

Award Committee: Patricia Strach, Chair, University at Albany, SUNY; Domingo Morel, Rutgers University; Alexander Hertel-Fernandez, Columbia University

Recipient: Melissa Sands, Harvard University Title: "Who Wants to Tax a Millionaire? Exposure to Inequality Reduces Support for Redistribution."

Theodore J. Lowi Policy Studies Journal Best Article Award

The Theodore J. Lowi Policy Studies Journal Best Article Award is given to recognize an article of particular distinction published at any time in Policy Studies Journal. Award Committee: Steve Teles, Chair, Johns Hopkins University; Kathryn Webb-Farley, Appalachian State University; Anthony Bertelli, New York University

Recipients: Hongtao Yi, The Ohio State University and John Scholz, Florida State University

Title: "Policy Networks in Complex Governance Subsystems: Observing and Comparing Hyperlink, Media, and Partnership Networks." Policy Studies Journal 44(3): 248-79.

\section{Excellence in Mentoring Award}

The Excellence in Mentoring Award has been established to recognize sustained efforts by a senior scholar to encourage and facilitate the career of emerging political scientists in the field of public policy. Award Committee: Donald Moynihan, Chair, University of Wisconsin, LaFollete; Christopher Howard, The College of William and Mary; Carolyn Barnes, Duke University

Recipient: David Weimer, University of Wisconsin, Madison

SECTION 05. POLITICAL ORGANIZATIONS AND PARTIES

\section{Emerging Scholars Award}

The Emerging Scholars Award is given to a scholar who has received his or her $\mathrm{PhD}$ within the last five years and whose career to date demonstrates unusual promise. Award Committee: Eric Heberlig, Chair, University of North Carolina at Charlotte; Tom Louwerse, Leiden University; Samara Klar, University of Arizona

Recipient: Liliana Mason, University of Maryland

\section{Jack Walker Award}

The Jack Walker Award recognizes an article published in the last two calendar years that makes an outstanding contribution to research and scholarship on political organizations and parties.

Award Committee: Michael Kowal, Chair, University of Massachusetts Amherst; Vineeta Yadav, Pennsylvania State University; Michael Heaney, University of Michigan

Recipients: Mike Franz, Bowdoin College; Erika Franklin Fowler, Wesleyan University; Travis Ridout, Washington State University
Title: "Loose Cannons or Loyal Foot Soldiers? Toward a More Complex Theory of Interest Group Advertising Strategies." American Journal of Political Science.

Honorable Mention: George Kernell, University of California, Los Angeles

Title: "Party Nomination Rules and Campaign Participation." Comparative Political Studies.

\section{Leon D. Epstein Outstanding Book Award}

The Leon D. Epstein Outstanding Book Award recognizes a book published in the last two calendar years that made an outstanding contribution to research and scholarship on political organizations and parties.

Award Committee: Jonathan Slapin, Chair, University of Essex; Sven-Oliver Proksch, McGill University; Fabio Rojas, Indiana University Bloomington

Recipients: Rory Treux, Princeton University Title: Making Autocracy Work: Representation and Responsiveness in Modern China. Cambridge University Press, 2016.

Recipients: Michael T. Heaney, University of Michigan, Ann Arbor and Fabio Rojas, Indiana University, Bloomington Title: Party in the Street: The Antiwar Movement and the Democratic Party after 9/11. Cambridge University Press, 2015.

\section{Samuel J. Eldersveld Career Achieve- ment Lifetime Award}

The Samuel J. Eldersveld Career Achievement Lifetime Award recognizes a scholar whose lifetime professional work has made an outstanding contribution to the field. Award Committee:Kay L. Schlozman, Chair, Boston College; Michael Laver, New York University; Tim LaPira, James Madison University

Recipient: Mathew McCubbins, Duke University

\section{POP Party Politics Best APSA Paper} Award

The POP/Party Politics Award recognizes the best paper delivered on a Political Organizations and Parties-sponsored panel at the preceding APSA Annual Meeting. Award Committee: Bruce Desmarais, Chair, Pennsylvania State University; Anika Guaja, The University of Sydney; Katie Marchetti, Dickinson College

Recipients: Jesse M. Crosson and Michael T. Heaney, University of Michigan Title: "Constructing Interest Group Coalitions." 
SECTION 06. PUBLIC ADMINISTRATION

\section{Herbert A. Simon Best Book Award}

The Herbert A. Simon Book Award is given for significant contributions to public administration scholarship.

Award Committee: Manuel Teodoro, Texas A\&M University; Sean Nicholson-Crotty, Indiana University; Jennifer Connolly, University of Miami

Recipients: Sean Gailmard, University of California, Berkeley and John Patty, Washington University

Title: Learning While Governing: Expertise and Accountability in the Executive Branch. University of Chicago Press, 2013.

\section{Paul A. Volcker Junior Scholar Research Grant Award}

The Paul A. Volcker Junior Scholar Research Grant Award is awarded to junior scholars researching public administration issues that affect governance in the United States and abroad. Proposals will be judged on their potential to shed new light on important public administration questions, their scholarly and methodological rigor, and their promise for advancing practice and theory development.

Award Committee: Alisa Hicklin Fryar, Oklahoma University; Julie Dolan, Macalester College; Daniel Hawes, Kent State University; Jennifer Dodge, University at Albany, SUNY

Recipient: Kristen Carroll, Texas A\&M University

\section{SECTION 07. CONFLICT PROCESSES}

\section{Lifetime Achievement Award}

The Lifetime Achievement award is given every other year in recognition of scholarly contributions that have fundamentally improved the study of conflict processes.

Award Committee: Benjamin O. Fordham, Chair, Binghamton University; Reşat Bayer, Koç University; Alyssa Prorok, University of Iowa

Recipient: John A. Vasquez, University of Illinois, Urbana-Champaign

\section{J. David Singer Data Innovation Award}

The J. David Singer Data Innovation Award is given biennially for the best data contribution to the study of any and all forms of political conflict, either within or between nation-states. Nominations must be made by a member of the Conflict Processes section. Self-nominations are encouraged. Award Committee: Kristian Skrede Gleditsch, Chair, University of Essex; Alex Braithwaite, University of Arizona; Patricia Sullivan, University of North Carolina at Chapel Hill

Recipients: Cullen Hendrix, University of Denver and Idean Salehyan, University of Texas at Dallas

Title: The Social Conflict Analysis Database (SCAD)

\section{Best Paper Award}

This award is given annually for the best paper written by one or more untenured scholars (graduate students, postdocs, or faculty) and presented as part of a conflict processes sponsored panel or poster session at the previous APSA Annual Meeting. Papers are eligible only if all authors are untenured at the time the paper is presented. Nominations must be made by a member of the Conflict Processes section. Selfnominations are encouraged.

Award Committee: Kathleen Gallagher Cunningham, Chair, University of Maryland, College Park; Shuhei Kurizaki, Waseda University; Nils W. Metternich, University College London

Recipients: Jessica A. Stanton, University of Pennsylvania and Neil Narang, University of California, Santa Barbara

Title: "A Strategic Logic of Attacking Aid Workers: Evidence from Violence in Afghanistan, 2008-2012."

SECTION 08. REPRESENTATION AND ELECTORAL SYSTEMS

\section{George H. Hallet Award}

The George H. Hallett Award is presented annually to the author of a book published at least 10 years ago that has made a lasting contribution to the literature on representation and electoral systems.

Award Committee: Pippa Norris, Chair, Harvard University; Oddbjørn Knutsen, University of Oslo; Ko Maeda, University of North Texas

Recipient: Anne Phillips, London School of Economics

Title: The Politics of Presence. Oxford University Press.

\section{Lawrence Longley Award}

The Lawrence Longley Award is given for the best article published in the previous year.
Award Committee: Rafaela Dancygier, Chair, Princeton University; Allen Hicken, University of Michigan; Kathleen Bawn, University of California, Los Angeles Recipients: Tarik Abou-Chadi and Matthias Orlowski, Humboldt-Universitat zu Berlin Title: "Moderate as Necessary: The Role of Electoral Competitiveness and Party Size in Explaining Parties' Policy Shifts." The Journal of Politics 78 (3): 868-81.

Recipients: Orit Kedar, Liran Harsgor, and Raz Sheinerman, Hebrew University of Jerusalem

Title: "Are Voters Equal under the Proportional Representation." American Journal of Political Science 6o (3): 676-91.

\section{Leon Weaver Award}

The Leon Weaver Award is given for the best paper presented at the previous year's APSA Annual Meeting at a panel sponsored by the Representation and Electoral Systems Division.

Award Committee: Amy Catalinac, New York University; Michael D. McDonald, Binghamton University; Jessica Trounstine, University of California, Merced

Recipient: Jana Morgan, University of Tennessee and Magda Hinojosa, Arizona State University

Title: "Women in Political Parties: Seen But Not Heard."

\section{SECTION 09. PRESIDENTS AND EXECUTIVE POLITICS}

\section{Richard E. Neustadt Award for Best Book on Executive Politics}

The Richard E. Neustadt Award for the Best Book on Executive Politics recognizes a book published during the year that contributed to research and scholarship on the American presidency.

Award Committee: Kenneth R. Mayer, Chair, University of Wisconsin, Madison; Lilly Goren, Carroll University; Sharece D. Thrower, Vanderbilt University; Ian Ostrander, Michigan State University Recipients: Douglas L. Kriner, Boston University and Eric Schickler, University of California, Berkeley

Title: Investigating the President: Congressional Checks on Presidential Power. Princeton University Press, 2016.

\section{Richard E. Neustadt Award for Best Reference Work on the Presidency}

The Richard E. Neustadt Award for the Best Reference Work on the Presidency 
recognizes a book on the presidency and executive politics published in the previous calendar year.

Award Committee: Kenneth R. Mayer, Chair, University of Wisconsin, Madison; Lilly Goren, Carroll University; Sharece D. Thrower, Vanderbilt University; Ian Ostrander, Michigan State University Recipients: John T. Woolley, University of California, Santa Barbara and Gerhard Peters, Citrus College

Title: The American Presidency Project.

\section{Presidents and Executive Politics Group Career Service Award}

The Presidential Research Group Career Service Award is given to an individual who has made important professional service contributions to the Presidents and Executive Politics section during his or her career. Award Committee: Jose D. Villalobos, Chair, University of Texas at El Paso, Adam L. Warber, Clemson University; MaryAnne Borrelli, Connecticut College; Paul J. Quirk, University of British Columbia

Recipient: Louis Fisher, The Constitution Project

\section{The Legacy Award}

The Legacy Award will be given to a living author for a book, essay, or article, published at least 10 years prior to the award year that has made a continuing contribution to the intellectual development of the fields of presidency and executive politics.

Award Committee: Karen M. Hult, Chair, Virginia Tech University; Mary E. Stuckey, Georgia State University; Jose Antonio Cheibub, Texas A\&M University; Alexander Bolton, Emory University Recipient: Stephen Skowronek, Yale University

Title: The Politics Presidents Make: Leadership from John Adams to Bill Clinton. Harvard University, Belknap Press, 1993.

\section{Founder's Best Paper Award}

The Founders Award-honoring James Sterling Young-recognizes the best paper on executive politics authored by a PhDholding scholar at the 2016 APSA Annual Meeting.

Award Committee: Gisela Sin, Chair, University of Illinois at Urbana-Champaign; Kenneth Lowande, Washington University in St. Louis; Kiki Caruson, University of South Florida

Recipients: Larry Rothenberg and Matthew Sweeten, University of Rochester
Title: "Analyzing Agency Choice with Text Analysis: The Case of the NLRB."

\section{Founder's Best Graduate Student Paper Award}

The Founders Award-honoring Peri Arnold-recognizes the best paper on executive politics presented by a graduate student at either the 2016 APSA Annual Meeting or at any regional meetings in 2016-2017.

Award Committee: Gary E. Hollibaugh, Jr., Chair, University of Notre Dame; Lara M. Brown, George Washington University; Anne Cizmar, Eastern Kentucky University; Jose-Luis Mendez, El Colegio de Mexico Recipient: Elizabeth Mann, University of Michigan

Title: "Presidential Policymaking at the State Level: Revision through Waivers?"

\section{Geroge C. Edwards, III Dissertation Award}

The George C. Edwards, III Dissertation Award is given for the best dissertation in presidency research completed and accepted during the previous two calendar years (January 1, 2015-December 31, 2016).

Award Committee: Shirley Anne Warshaw, Chair, Gettysburg College; Susan M. Miller, University of South Carolina; Daniel E. Ponder, Drury University; Martin Lodge, London School of Economics

Recipient: Elizabeth Mann, University of Michigan

Title: "Presidential Policymaking at the State Level: Revision Through Waivers?"

\section{SECTION 10. POLITICAL}

\section{METHODOLOGY}

\section{Society for Political Methodology Poster Award}

This award recognizes the best political methodology poster given at any political science conference in the preceding year.

Award Committee: Neal Beck, New York University; Ines Levin, University of California, Irvine; Sarah Mitchell, University of Iowa; Jeff Gill, Washington University in St. Louis

Recipient: Dana Higgins, Harvard University

Title: "Disaggregating Data Using Multiple Imputation: Battle Related Deaths."

\section{Career Achievement Award}

The Career Achievement Award honors an outstanding career of intellectual accomplishment and service to the profession in the Political Methodology field. Award Committee: Rob Franzese, University of Michigan; Lonna Atkeson, University of New Mexico; Kosuke Imai, Princeton University; Simon Jackman, University of Sydney; Wendy Tam Cho, University of Illinois at Urbana-Champaign

Recipient: Robert Erikson, Columbia University

\section{Excellence in Mentoring Award}

The Society for Political Methodology Excellence in Mentoring Award honors members of the Society for Political methodology who have demonstrated an outstanding commitment to mentoring and advising graduate and/or undergraduate students-particularly those from underrepresented groups.

Award Committee: Henry Brady, University of California, Berkeley; Phil Schrodt, Pennsylvania State University; Maya Sen, Harvard University

Recipient: R. Michael Alvarez, California Institute of Technology

\section{Warren Miller Prize}

The Warren Miller Prize is given for the best article in political analysis.

Award Committee: Patrick Brandt, University of Texas at Dallas; Devin Caughey, Massachusetts Institute of Technology; R. Michael Alvarez, California Institute of Technology; Sunshine Hillygus, Duke University

Recipient: Joel A. Middleton, University of California, Berkeley; Mark A. Scott, New York University; Ronli Diakow, New York City Department of Education; Jennifer L. Hil, New York University

Title: "Bias Amplification and Bias Unmasking." Political Analysis 24 (4): 307-23.

\section{Statistical Software Award}

The Statistical Software Award recognizes statistical software that has made a significant contribution to the advancement of political science.

Award Committee: Justin Esarey, Rice University; Jamie Monogan, University of Georgia; Arthur Spirling, New York University

Recipients: Rocio Titunik, University of Michigan, Gonzalo Vazquez-Bare, University of Michigan; Sebastian Calonico, University of Miami; Matias D. Cattaneo, University of Michigan; Max H. Farrell, University of Chicago; Michael Jansson, 
University of California, Berkeley; Xinwei Ma, University of Michigan

Title: For the rdrobust, rdlocrand, rddensity, rdpower statistical packages, http:// sites.google.com/site/rdpackages/.

\section{Emerging Scholar Award}

The Emerging Scholar Award honors a young researcher, within 10 years of a degree, who is making notable contributions to the field of political methodology. Award Committee: Lonna Atkeson, University of New Mexico; Walter Mebane, University of Michigan; Jeff Gill, Washington University in St. Louis

Recipient: Betsy Sinclair, Washington University in St. Louis

\section{Harold F. Gosnell Prize}

The Harold Gosnell Prize recognizes the best work of political methodology presented at a political science conference in the previous year.

Award Committee: Michael Peress, Stony Brook University and Brandon Stewart, Princeton University

Recipient: Matthew Blackwell, Harvard University

Title: "Instrumental Variable Methods for Conditional Effects and Casual Interaction in Voter Mobilization Experiments."

\section{John T. Williams Dissertation Prize}

In recognition of John T. Williams' contribution to graduate training, this prize has been established for the best dissertation proposal in the area of political methodology.

Award Committee: Justin Grimmer, University of Chicago; Matt Blackwell, Harvard University; Teppei Yamamoto, Massachusetts Institute of Technology

Recipient: Naoki Egami, Princeton University

\section{SECTION 11. RELIGION AND POLI-} TICS

\section{Hubert Morken Book Award}

The Hubert Morken Award is given for the best publication dealing with religion and politics published during the last two years.

Award Committee: Nandini Deo, Chair, Lehigh University; Kevin Den Dulk, Calvin College; Ben Schewel, University of Virginia; Helge Arsheim, University of Oslo

Recipient: Avi Spiegel, University of San Diego
Title: The New Politics of Religion in Morocco and the Arab World. Princeton University Press, 2015/2017.

\section{Aaron Wildavsky Dissertation Award}

The Aaron Wildavsky Dissertation Award recognizes the best dissertation on religion and politics successfully defended within the last two years.

Award Committee: Nukhet Sandal, Chair, Ohio University; Ryan Claassen, Kent State University; Mona Oraby, Indiana University; Gizem Arikan, Yasar University Recipient: Robert Braun, Northwestern University

Title: "Religious Minorities and Resistance to Genocide: Christian Protection of Jews in the Low Countries during the Holocaust."

\section{Kenneth D. Wald Best Graduate Stu- dent Paper Award}

The Kenneth D. Wald Best Graduate Student Paper Award is given annually to a conference paper studying any aspect of religion and politics presented by a $\mathrm{PhD}$ student in political science. The conference can be affiliated with any of the US-based political science associations or a conference affiliated with another association, such as the Society for the Scientific Study of Religion, the American Academy of Religion, the Middle East Studies Association, or the International Studies Association, as long as the paper was written by a student or students enrolled in a graduate program in political science.

Award Committee: Matthew J. Nelson, Chair, School of Oriental and African Studies, University of London; Jeremy Menchik, Boston University; Ted G. Jelen, University of Nevada; David Buckley, University of Louisville

Recipient: Egor Lazarev, Columbia University

Title: "Choosing Between Laws: Preferences for Alternative Legal Systems in Chechnya."

\section{Ted G. Jelen Best Article Award}

This prize is awarded to the best article published in the section's journal Politics and Religion. The winner of the award is selected by the journal's editors.

Award Committee: Paul A. Djupe, Chair, Denison University; Angelina R. Wilson, University of Manchester

Recipients: Sarah Allen Gershon, Georgia State University; Adrian D. Pantoja, Pitzer College; J. Benjamin Taylor, University of North Carolina at Wilmington
Title: "God in the Barrio? The Determinants of Religiosity and Civic Engagement among Latinos in the United States." Politics \& Religion 9 (1): 84-110.

\section{SECTION 13. URBAN AND LOCAL POLITICS}

Norton Long Career Achievement Award The Norton Long Career Achievement Award is presented annually to a scholar who has made distinguished contributions to the study of urban politics over the course of a career through scholarly publication, the mentoring of students, and public service

Award Committee: David Imbroscio, Chair, University of Louisville; Barbara Ferman, Temple University; Jill Gross, Hunter College, CUNY

Recipient: H.V. Savitch, University of Louisville

\section{Best Paper Award}

The Best Paper Award is given for the best paper given at an Urban Politics Section panel at the previous year's APSA Annual Meeting.

Award Committee: Genie Stowers, Chair, San Francisco State University; Ann Bowman, Texas A\&M University; Laura Reese, Michigan State University

Recipients: Melody Crowder-Meyer, The University of the South; Shana Kushner Gadarian, Syracuse University; Jessica Trounstine, University of California, Merced; Kau Vue, University of California, Merced

Title: "A Different Kind of Disadvantage: Candidate Race, Electoral Institutions, and Voter Choice."

\section{Clarence Stone Scholar Award}

The Clarence Stone Scholar Award recognizes up to two young scholars who are making a significant contribution to the study of urban politics. The award is to be given to up to two post-PhD scholars who are in their career (pre-tenure, or recently advanced within the last three years).

Award Committee: Ronald K. Vogel, Ryerson University

Recipients: Jack Lucas, University of Calgary and Domingo Morel, Rutgers University, Newark

\section{Susan Clarke Young Scholars Award}

The Susan Clarke Young Scholars award recognizes scholars who completed their 
$\mathrm{PhD}$ within the last three years (or are ABDs).

Award Committee: Ronald Vogel, Chair, Ryerson University; Tom Vicino, Northeastern University; Yue Zhang, University of Illinois at Chicago

Recipients: Nazita Lajevardi, Michigan State University; David Kaufmann, University of Bern; Diane Wong, Cornell University; Sally Lawton, Johns Hopkins University

\section{Best Dissertation Award}

The Best Dissertation Award is given annually for the best dissertation on urban politics accepted in the previous year.

Award Committee: Martin Horak, Chair, University of Western Ontario; Stefanie Chambers, Trinity College; Paul Kantor, Fordham University

Recipient: Iza (Yue) Ding, University of Pittsburgh

Title: "Invisible Sky, Visible State: Environmental Governance and Political Support in China."

\section{Bryan Jackson Dissertation Research on Minority Politics Award}

The Bryan Jackson Award recognizes the outstanding scholarship by a graduate student studying racial and ethnic politics in an urban setting.

Award Committee: Dianne Pinderhughes, Chair, University of Notre Dame; Susan Clarke, University of Colorado, Boulder; Arnold Fleischmann, Eastern Michigan University

Recipient: Patricia Posey, University of Pennsylvania

Title: "Refinancing the American Dream: the Consequences of Targeted Financial Policy for Political and Radical Inequality in the United States."

\section{Dennis Judd Best Book Award}

The Best Book Award recognizes the best book on urban politics published in the previous year.

Award Committee: Warren Magnusson, Chair, University of Victoria; Jeff Paller, University of San Francisco; Cynthia Jackson-Elmoore, Michigan State University; Annika Hinze, Fordham University; Elizabeth Strom, University of South Florida

Recipient: Margaret (Peggy) Kohn, University of Toronto

Title: The Death and Life of the Urban Com monwealth. Oxford University Press, 2016.
SECTION 15. SCIENCE, TECHNOLOGY, AND ENVIRONMENTAL POLITICS

\section{Elinor Ostrom Career Achievement Award}

The Elinor Ostrom Career Achievement Award is given to an individual in recognition of a lifetime contribution to the study of science, technology, and environmental politics.

Award Committee: Daniel Aldrich, Chair, Northeastern University; Chris Weible, University of Colorado, Denver; Eric Smith, University of California, Santa Barbara

Recipient: David Vogel, University of California, Berkeley

\section{Emerging Young Scholar Award}

The Emerging Young Scholar Award is given in recognition of a researcher, within 10 years of a $\mathrm{PhD}$ degree, who is making notable contributions to the field of science, technology, and environmental politics.

Award Committee: Ronald Mitchell, University of Oregon; Megan Mullin, Duke University; Ann Bowman, Texas A\&M University

Recipient: Jessica Green, New York University

\section{Lynton Keith Caldwell Award}

The Lynton Keith Caldwell Award is given for the best book on environmental politics and policy published in the past three years.

Award Committee: Chris Bosso, Northeastern University; Deserai Crow, University of ColoradoDenver; Rob DeLeo, Bentley University

Recipient: Leigh Raymond, Purdue University

Title: Reclaiming the Atmospheric Commons: The Regional Greenhouse Gas Initiative and a New Model of Emissions Trading. MIT Press, 2016.

Virginia M. Walsh Dissertation Award The Virginia M. Walsh Dissertation Award-in honor of a young scholar who tragically passed away-is given for the best dissertations in the field of science, technology, and environmental politics. Award Committee: David Konisky, Indiana University Bloomington; Amy Below, Oregon State University

Recipient: Yue (Iza) Ding, University of Pittsburgh
Title: "Invisible Sky, Visible State: Environmental Governance and Political Support in China."

\section{Don K. Price Award}

The Don K. Price Award recognizes the best book on science, technology, and environmental politics published in the last year.

Award Committee: Jennifer Hadden, University of Maryland, College Park; Leah Stokes, University of California, Santa Barbara; Kirsten Rodine Hardy, Northeastern University

Recipient: Mark Buntaine, University of California, Santa Barbara

Title: Giving Aid Effectively: The Politics of Environmental Performance and Selectivity at Multilateral Development Banks. Oxford University Press, 2016.

Recipient: Mark Zachary Taylor, Georgia Tech

Title: The Politics of Innovation: Why Some Countries Are Better Than Others at Science and Technology. Oxford University Press, 2016.

\section{Best Paper Award}

The Best Paper Award is given for the best paper published in a relevant journal in the last two years. Relevant journals include political science, public administration, public policy, interdisciplinary environmental science, and science and technology studies journals.

Award Committee: Arun Agrawal, Chair, University of Michigan; Tanya Corbin, Radford University; Samantha Mosier, Missouri State University

Recipient: Erika S. Simmons, University of Wisconsin, Madison

Title: "Market Reforms and Water Wars." World Politics 68 (1): 37-73.

\section{Paul A. Sabatier Best Conference Paper Award}

The Paul A. Sabatier Best Conference Paper Award is given for the best paper on science, technology, and environmental politics presented at the previous year's APSA Annual Meeting.

Award Committee: Chris Koski, Reed College; Heather Hodges, University of California, Santa Barbara; Alan Steinberg, Rice University

Recipient: Shiran Shen, Stanford University

Title: "The Inconvenient Truth of the Political Pollution Cycle: Theory and Evidence from Chinese Prefectures." 
SECTION 16. WOMEN AND POLITICS RESEARCH

\section{Best Dissertation Award}

This award is given for the best dissertation on women and politics completed and accepted in the previous year.

Award Committee: Rosalyn Cooperman, Chair, University of Mary Washington; Christina Xydias, Clarkson University; Melanie Hughes, University of Pittsburgh

Recipient: Catherine Reyes-Householder, Cornell University

Title: "Presidents, Power, and Pro-Women Change."

\section{Best Paper Award}

This award is given for the best paper presented at the previous year's annual meeting in the field of women and politics.

Award Committee: Amy Atchison, Chair, Valparaiso University; Sarah Allen Gershon, Georgia State University; Amy Cabrera Rasmussen, California State University, Long Beach

Recipients: Mona Morgan-Collins, University of Pennsylvania and Dawn Teele, University of Pennsylvania

Title: "After the Vote: Programmatic Preferences and Women's Loyalty."

\section{Okin-Young Award in Feminist Politi- cal Theory}

The Okin-Young Award in Feminist Political Theory, co-sponsored by Women and Politics, Foundations of Political Theory, and the Women's Caucus for Political Science, commemorates the scholarly, mentoring, and professional contributions of Susan Moller Okin and Iris Marion Young to the development of the field of feminist political theory. This annual award recognizes the best paper on feminist political theory published in an English language academic journal during the previous calendar year.

Award Committee: Kathy Ferguson, Chair, University of Hawaii; Jennet Kirkpatrick, Arizona State University; Sina Jo Kramer, Loyola Marymount University

Recipient: Lorna Bracewell, University of Nebraska at Kearney

Title: "Beyond Barnard: Liberalism, Antipornography Feminism, and the Sex Wars." Signs. 42 (1): 23-48.
SECTION 17. FOUNDATIONS OF

\section{POLITICAL THEORY}

\section{First Book Award}

The First Book Award is given for a first book by a scholar in the early stages of his or her career in the area of political theory or political philosophy.

Award Committee: Joshua Foa Dienstag, Chair, University of California, Los Angeles; Keally McBride, University of San Francisco; Jeremy Elkins, Bryn Mawr College Recipient: Joseph Fischel, Yale University Title: Sex and Harm in the Age of Consent. University of Minnesota Press, 2016.

\section{Best Paper Award}

The Best Paper Award is given for the best paper presented on a foundations panel at the previous year's APSA Annual Meeting. Award Committee: Stefan Dolgert, Chair, Brock University; Laurie Naranch, Siena College; Lida Maxwell, Trinity College

Recipient: Zach Reyna, Johns Hopkins University

Title: "Bovine Bellow and Aquiline Vision: Aquinas' Ecological Approach to Law \& Politics."

\section{SECTION 18. INFORMATION TECH- NOLOGY AND POLITICS}

\section{Best Book Award}

The Best Book Award recognizes the best book in the area of information technology and politics. The contest is limited to books published in the previous calendar year. Award Committee: Jeff Gulati, Bentley University; Cristian Vaccari, University of London, Royal Holloway; Katherine Haenschen, Princeton University

Recipient: Daniel Kreiss, University of North Carolina at Chapel Hill

Title: Prototype Politics: Technology-Intensive Campaigning and the Data of Democracy. Oxford University Press, 2016.

\section{Best Published Article Award}

The Best Published Article Award recognizes the best scholarly article published about information technology and politics. The contest is limited to articles published in the calendar year.

Award Committee: Pablo Barbera, Chair, University of Southern California; Katy Pearce, University of Washington, Seattle;
Kevin Wallsten, California State University, Long Beach

Recipient: Cristian Vaccari, University of London, Royal Holloway

Title: "Online Mobilization in Comparative Perspective: Digital Appeals and Political Engagement in Germany, Italy, and the United Kingdom." Political Communication 3(1) 4: 69-88.

\section{Best Conference Paper Award}

The Best Conference Paper Award recognizes the best conference paper in the area of information technology and politics.

Award Committee: Yannis Theocharis, University of Mannheim; Toni Pole, Montclair State University; Andreas Jungherr, University of Konstanz

Recipient: Hannah Chapman, University of Wisconsin, Madison

Title: "Shoring Up Autocracy: Participatory Technologies and Regime Support in Putin's Russia."

\section{SECTION 19. INTERNATIONAL} SECURITY AND ARMS CONTROL

\section{Kenneth N. Waltz Dissertation Award}

Kenneth N. Waltz Dissertation Award is awarded to a successfully defended doctoral dissertation on any aspect of security studies, which has been submitted in final, library copy in the previous calendar year. The committee welcomes nominations for dissertations employing any approach (historical, quantitative, theoretical, policy analysis, etc.) to any topic in the field of security studies. Manuscripts are judged according to 1 ) originality in substance and approach; 2) significance for scholarly or policy debate; 3 ) rigor in approach and analysis; and 4) power of expression.

Award Committee:Joshua Shifrinson, Chair, Texas A\&M University; Dara Kay Cohen, Harvard University; Lindsay Cohn, Naval War College; Matt Fuhrmann, Texas A\&M University; Aaron Rapport, University of Cambridge

Recipient: Mark Bell, Massachusetts Institute of Technology

Title: "NuclearWeapons and Foreign Policy." Honorable Mention: Peter White, University of Maryland, College Park

Title: "Crises and Crisis Generations: International Conflict and Military Participation on Politics." 
SECTION 20. COMPARATIVE

POLITICS

\section{Sage Best Paper Award}

The Sage Best Paper Award is given to the best paper in the field of comparative politics presented at the previous year's APSA Annual Meeting.

Award Committee: William C. Clark, Texas A\&M University; Adrienne LeBas, American University; Anibal Perez-Linan, University of Pittsburgh

Recipient: Barry Driscoll, Grinnell College

Title: "Elections and Goods Provision in Decentralized Developing Countries."

Honorable Mention: Junyan Jiang, University of Chicago; Tianguang Meng, Tsinghua University; Qing Zhang, Columbia University

Title: "From Internet to Safety Net: The Policy Consequences of Online Participation in China."

Honorable Mention: Kenneth F. Greene, University of Texas at Austin

Title: "Why Vote Buying Fails: Campaign Effects and the Elusive Swing Voter."

\section{Luebbert Best Book Award}

The Luebbert Book Award is given for the best book in the field of comparative politics published in the previous two years.

Award Committee: Lisa Blaydes, Chair, Stanford University; Susan Stokes, Yale University; Juan Pablo Luna, Pontifica Universidad Catolica de Chile; Tariq Thachil, Vanderbilt University

Recipient: Anna Grzymala-Busse, Stanford University

Title: Nations Under God. Princeton University, 2015 .

\section{Greg Luebbert Paper Award}

The Luebbert Article Award is given for the best article published in the American Political Science Review in the field on comparative politics in the prior two calendar years.

Award Committee: Thomas D. Lancaster, Chair, Emory University; Anna De La O, Yale University; Jonathan Slapin, Essex University

Recipient: Robert Braun, Northwestern University

Title: "Religious Minorities and Resistance to Genocide: The Collective Rescue of Jews in the Netherlands during the Holocaust." American Political Science Review 110 (1): 127-47.

\section{Lijphart/Przeworski/Verba Data Set Award}

The Data Set Award recognizes a publicly available data set that has made an important contribution to the field of comparative politics.

Award Committee: Michael Bernhard, Chair, University of Florida; Jennifer Ghandi, Emory University; Frederick Solt, University of Iowa

Recipients: Thomas Richter, GIGA, German Institute of Global and Area Studies and Viola Lucas, Universitat Konstanz and GIGA, German Institute of Global and Area Studies

Title: "Global State Revenue and Expenditures" Dataset, http:/dx.dol.org// 10.7802/1290.

\section{SECTION 21. EUROPEAN POLITICS AND SOCIETY}

\section{Best Article Award}

This award is given for the best article dealing with European Politics \& Society published in the last year.

Award Committee: Dorothee Bohle, Chair, European University Institute; Evgeny Finkel, George Washington University; Wade Jacoby, Brigham Young University Recipients: Lisa Blaydes, Stanford University and Christopher Paik, New York University, Abu Dhabi

Title: "The Impact of Holy Land Crusades on State Formation: War Mobilization, Trade Integration, and Political Development in Medieval Europe." International Organization 70(3): 551-86.

Recipient: Robert Braun, Northwestern University

Title: "Religious Minorities and Resistance to Genocide: The Collective Rescue of Jews in the Netherlands during the Holocaust." American Political Science Review 110(1): 127-47.

\section{Best Book Award}

The Best Book Award is given for the best book on European Politics and society published in the previous year.

Award Committee: Anna Grzymala-Busse, Chair, Stanford University; Harris Mylonas, George Washington University; Daniel Ziblatt, Harvard University

Recipient: Zeynep Bulutgil, Tufts University

Title: The Roots of Ethnic Cleansing in Europe. Cambridge University Press, 2016.

\section{Ernst B. Haas Best Dissertation} Award

The Ernst B. Haas Best Dissertation Award is given for the best dissertation on European politics and society filed during the previous year.

Award Committee: Dan Kelemen, Chair, Rutgers University; Dawn Teele, University of Pennsylvania; Mark Vail, Tulane University

Recipient: Robert Braun, Northwestern University

Title: "Religious Minorities and Resistance to Genocide: Christian Protection of Jews in the Low Countries during the Holocaust." Cornell University, 2016.

Honorable Mention: Osman Balkan, Swarthmore College

Title: "Death on the Move: Burial, Repatriation, and the Politics of Belonging among Muslims in Germany." University of Pennsylvania, 2016.

\section{Best Paper Award}

The Best Paper Award is given for the best paper given on European Politics and Society section-sponsored panels at previous APSA Annual Meetings.

Award Committee: Stanislav Markus, Chair, Moore School of Business, University of South Carolina; Orfeo Fioretos, Temple University; Daphne Halikiopoulou, University of Reading

Recipient:Alexander Reisenbichler, George Washington University

Title: "The Politics of Entrenchment: Growth Models and Housing Finance in the United States and Germany."

\section{Peter Mair Memorial Award}

The Peter Mair Memorial Award will fund the travel of two young scholars to attend the APSA Annual Meeting. Named in memory of Peter Mair, one of the foremost scholars of European politics, the award is meant explicitly to enable young scholars of European politics without adequate funding to present a paper in one of the panels organized by the European Politics and Society section.

Award Committee: Chris Hanretty, Chair, University of East Anglia; Karen Anderson, University of Southampton; Maurits van der Veen, College of William \& Mary

Recipient: Marta Lorimer, London School of Economics

Title: "Challenging EU Legitimacy from a Radical Right Perspective: The Case of the ENF." 
SECTION 22. STATE POLITICS AND POLICY

\section{Career Achievement Award}

The Career Achievement Award is given every biennium to a political scientist who has made a significant lifetime contribution to the study of politics and public policies in the American states.

Award Committee: Thad Kouser, Chair, University of California, San Diego; Nelson Dometrius, Texas Tech University; Caroline Tolbert, University of Iowa

Recipient: Tom Carsey, University of North Carolina at Chapel Hill

\section{Christopher A. Mooney Dissertation Award}

This award is given for the best dissertation in American state politics and policy completed during the previous calendar year. Award Committee: Belinda Davis, Chair, Louisiana State University; Damon Cann, Utah State University; Alexandra Filindra, University of Illinois at Chicago

Recipient: Matthew N. Tokeshi, Williams College

Title: "White Voters' Response to African American Candidates for High-Profile Statewide Offices."

\section{Best Article Award}

This award recognizes the best journal article on US state politics or policy published during the previous calendar year in any peer-reviewed journal.

Award Committee: Frederick Boehmke, Chair, University of Iowa; Elizabeth Rigby, George Washington University; Carlisle Rainey, Texas A\&M University

Recipients: Devin Caughey and Christopher Warshaw, Massachusetts Institute of Technology

Title: "The Dynamics of State Policy Liberalism, 1936-2014." The American Journal of Political Science 6o(4): 899-913.

\section{Virginia Gray Best Book Award}

This award is given annually to the best political science book published on the subject of US state politics or policy in the preceding three calendar years. Thus, books would be eligible to be considered for the award for three years.

Award Committee: Marjorie SarbaughThompson, Wayne State University; Sarah Anzia, University ofCalifornia, Berkely; Todd Makse, Florida International Univesity Recipients: Jeffrey J. Harden, University of Notre Dame
Title: Multidimensional Democracy: A Supply and Demand Theory of Representation in American Legislatures. Cambridge University Press, 2016.

\section{SPPQ Best Paper Award}

The State Politics and Policy Quarterly Best Paper Award is given for the best paper on state politics and policy presented at any professional meeting in the previous calendar year.

Award Committee: Neal Woods, University of South Carolina, Robert McGrath, George Mason University; Karl Klarner, University of Florida

Recipients: Christina Ladem, University of Colorado; Jeffrey Harden, University of Notre Dame; Jason Windett, University of North Carolina at Charlotte

Title: "Follow the Leader: Prominent Female Politicians and the Emergence of Women Candidates for Public Office."

\section{Mac Jewell Enduring Contribution Award}

This award is presented every three years to a political science book on the subject of US state politics or policy published at least 10 years prior to the award being bestowed that stands as an enduring contribution to the literature. Such books would be those classic works frequently assigned in graduate seminars, typically found on the bookshelves of state politics scholars, and that have been crucial in setting the direction of scholarship the field since their publication.

Award Committee: John McIver, University of Texas at Austin; William Berry, Florida State University; Ann O. Bowman, Texas A\&M University

Recipients: Virginia Gray, University of North Carolina at Chapel Hill; Russel L. Hanson, Indiana University; Thad Kousser, University of California, San Diego

Title: Politics in the American States: A Comparative Analysis, 11th Edition. CQPress, 2017.

\section{SECTION 23. POLITICAL COMMUNI- CATION}

\section{Timothy E. Cook Best Graduate Stu- dent Paper Award}

The Cook Award recognizes the best paper on political communication presented by a graduate student at the previous year's APSA Annual Meeting.

Award Committee: Yanna Krupnikov, Chair, Stony Brook University; Ashley Muddiman,
University of Kansas; Bethany Conway, California Polytechnic State University, San Luis Obispo

Recipient: Fabian Neuner, University of Michigan

Title: "From a 'Central Organizing Idea' in a Frame to a 'Central Organizing Idea' in the Brain: The Psychology of Framing Effects Revisited."

\section{Paul Lazarsfeld Best Paper Award}

The Paul Lazarsfeld Award recognizes the best paper on political communication presented at the previous year's APSA Annual Meeting.

Award Committee: Leticia Bode, Georgetown University; Andrew Chadwick, Royal Holloway, University of London; Deen Freelon, American University

Recipients: Brendan J. Nyhan, Dartmouth University and Jason Reifler, University of Exeter

Title: "Do People Actually Learn from FactChecking? Evidence from a Longitudinal Study during the 2014 Campaign."

\section{Thomas E. Patterson Best Disserta- tion Award}

This award recognizes one outstanding doctoral dissertation in political communication annually. To be considered for the award, the dissertation research must pertain to some aspect of political communication.

Award Committee: Kathleen Hall Jamieson, Chair, University of Pennsylvania; Regina Lawrence, University of Lawrence; Lauren Copeland, Baldwin Wallace University

Recipient: Benjamin Toff, University of Wisconsin, Madison

Title: "The Blind Scorekeepers: Journalism, Polling and the Battle to Define Public Opinion in American Politics."

\section{Murray Edelman Lifetime Distin- guished Career Award}

The Murray Edelman Distinguished Career Award recognizes a lifetime contribution to the study of political communication.

Award Committee: Rasmus Kleis Nielson, Chair, University of Oxford; Patricia Moy, University of Washington; Mary Stuckey, Georgia State University; Kevin Coe, University of Utah

Recipient: Gadi Wolfsted, The Hebrew University of Jerusalem

\section{Best Article Award}

This award recognizes the best article published in the field of political communication in the previous calendar year. 
Award Committee: David Karpf, Chair, George Washignton University; Nick Anstead, London School of Economics; Emily Thorson, Boston College

Recipient: Leticia Bode, Georgetown University

Title: "Political News in the News: Learning Politics from Social Media." Mass Communication and Society 19(1): 24-48.

\section{Doris Graber Outstanding Book Award}

The Doris Graber Outstanding Book Award recognizes a book that has made a significant theoretical, methodological, and/or empirical contribution to political communication scholarship in the last decade. Award Committee: Yphtach Lelkes, Chair, University of Pennsylvania; Abby Jones, Philadelphia University; Sharon Jarvis, University of Texas at Austin

Recipient: Diana Mutz, University of Pennsylvania

Title: In-Your-Face Politics: The Consequences of Uncivil Media. Princeton University Press, 2015 .

\section{SECTION 24. POLITICS AND} HISTORY

\section{J. David Greenstone Book Award}

The J. David Greenstone Book Award recognizes the best book in history and politics in the past two calendar years. Award Committee: Julie Novkov, Chair, University of Albany, SUNY; Monica Prasad, Northwestern University; Rebecca Thorpe, University of Washington, Seattle; Jeffrey Winters, Northwestern University

Recipient: Eric Schickler, University of California, Berkeley

Title: Racial Realignment: The Transformation of American Liberalism, 1932-1965. Princeton University Press, 2016.

Recipient: Sarah Staszak, Princeton University

Title: No Day in Court: Access to Justice and the Politics of Judicial Retrenchment. Oxford University Press, 2015.

Honorable Mention: Sheena Chestnut Greitens, University of Missouri

Title: Dictators and Their Secret Police: Coercive Institutions and State Violence. Cambridge University Press, 2016.

\section{Mary Parker Follett Award for Best Article}

The Mary Parker Follett Award recognizes the best article on politics and history published in the previous year.
Award Committee: Dara Strolovitch, Chair, Princeton University; Cheng Chen, University of Albany, SUNY; Deondra Rose, Duke University; Bo Rothstein, University of Oxford

Recipient: Anna Grzymala-Busse, Stanford University

Title: "Weapons of the Meek: How Churches Influence Public Policy." World Politics 68 (1): $1-36$.

\section{Walter Dean Burnham Dissertation Award}

The Walter Dean Burnham Award is given for the best dissertation in the field of politics and history.

Award Committee: Bartholomew Sparrow, Chair, University of Texas at Austin; Michael Fortner, CUNY; Kanta Murali, University of Toronto

Recipient: Robert Braun, Northwestern University

Title: "Religious Minorities and Resistance to Genocide"

Recipient: Daniel Koss, Academia Sinica, Taiwan

Title: "Where the Party Rules: Party-Based Authoritarianism and the Reach of the State."

\section{SECTION 25. POLITICAL ECONOMY}

\section{Michael Wallerstein Award}

The Michael Wallerstein Award is given for the best published article in political economy in the previous calendar year.

Award Committee: Laia Balcells, Chair, Georgetown University; Alexander Kuo, Cornell University; Boliang Zhu, Pennsylvania State University

Recipients: Rachel Wellhausen, University of Texas at Austin and Leslie Johns, University of California, Los Angeles

Title: "Under One Roof: Supply Chains and the Protection of Foreign Investment." American Political Science Review 110(1): 31-51.

\section{William H. Riker Book Award}

The Best Book Award, named for William H. Riker, is given for the best book on political economy published during the past three calendar years.

Award Committee: Pablo Beramendi, Duke University; Ernesto Calvo, University of Maryland; Rachel Wellhausen, University of Texas at Austin

Recipient: Gary Cox, Stanford University Title: Making Sovereign Promises: Monopoly Brokerage and the Rise of the English State. Cambridge University Press, 2016.
Honorable Mention: Kate Baldwin, Yale University

Title: The Paradox of Traditional Chiefs in Democratic Africa. Cambridge University Press, 2015.

\section{Mancur Olson Best Dissertation Award}

The Best Dissertation Award, named for Mancur Olson, is given for the best dissertation in political economy completed in the previous two years.

Award Committee: Margit Tavits, Chair, Washington University in St. Louis; Charlotte Cavaille, Georgetown University; Yuen Yuen Ang, University of Michigan

Recipient: Emily Sellars, Texas A\&M University

Title: "Essays on Emigration and Politics."

\section{Fiona McGillivray Prize Best Paper Award}

The Fiona McGillivray Prize is given for the best paper in political economy presented at the previous year's APSA Annual Meeting.

Award Committee: Monika Nalepa, Chair, University of Chicago; Alberto Simpser, ITAM; Yuhua Wang, Harvard University

Recipient: Alexander Hertel-Fernandez, Columbia University

Title: "Employers as Political Machines."

\section{SECTION 27. NEW POLITICAL} SCIENCE

\section{Christian Bay Best Paper Award}

The Christian Bay Award recognizes the best paper presented on a New Political Science panel at the previous year's APSA Annual Meeting.

Award Committee: Jocelyn Boryczka, Chair, Fairfield University; William Niemi, Western State University; Brian Waddell, University of Connecticut

Recipient: Timothy Weaver, University at Albany, SUNY

Title: "A City of Citizens: Social Justice and Urban Social Citizenship."

\section{Michael Harrington Book Award}

The Michael Harrington Book Award recognizes an outstanding book that demonstrates how scholarship can be used in the struggle for a better world.

Award Committee: Katherine Young, Chair, University of Hawaii at Hilo; Courtenay 
Daum, Colorado State University; Ruth Groff, Saint Louis University

Recipient: Peter Dauvergne, University of British Columbia

Title: Environmentalism of the Rich. MIT Press. 2016.

\section{Richard Cloward and Francis Fox Piven Award}

The Richard Cloward and Frances Fox Piven Award recognizes an activist group, in the region of the APSA Annual Meeting that puts the ideals of the New Political Science Section-"to make the study of politics relevant to the struggle for a better world"-into practice.

Award Committee: Sarah Surak, Chair, Salisbury University; Jeffrey Broxmeyer, University of Toledo; Sean Parson, Northern Arizona University; Frances Fox Piven, honorary, Graduate Center, CUNY Recipient: LeftRoots

\section{Charles A. McCoy Career Achieve- ment Award}

The Charles A. McCoy Career Achievement Award recognizes a progressive political scientist who has had a long, successful career as a writer, teacher, and activist.

Award Committee: Laura Olson, Chair, Lehigh University; Joseph Peschek, Hamline University; Kent Worcester, Manhattan Marymount College

Recipient: Mark Kesselman, Columbia University

\section{Stephen Eric Bronner Dissertation Award}

This award is for an outstanding political science dissertation finished within the previous year of the APSA Annual Meeting which exemplifies the commitment to use scholarship in the struggle for a better world.

Award Committee: Dean Snyder, Chair, Antioch College; F. Peter Wagner, University of Wisconsin, Whitewater; Andrew Scerri, Virginia Tech; Stephen Eric Bronner, honorary, Rutgers University

Recipient: Kevin Funk, Spring Hill College Title: "Between National Attachments, Rooted Transnationalism, and Borderless Utopias: Searching for Imagined Communities in Latin America's Booming Economic Relations with the Arab World." University of Florida, 2016.

SECTION 28. POLITICAL

\section{PSYCHOLOGY}

Hazel Gaudet Erskine Political Psychology Career Achievement Award

The Political Psychology Career Achievement Award is awarded biennially to recognize a scholar whose lifetime scholarship and service to the profession has made an outstanding contribution to the field of political psychology.

Award Committee: Nicholas Valentino, Chair, University of Michigan; James N. Druckman, Northwestern University; Laura Stoker, University of California, Berkeley Recipient: James H. Kuklinski, University of Illinois at Urbana-Champaign

\section{Robert E. Lane Best Book Award}

The Robert E. Lane Award recognizes the best book in political psychology published in the past year.

Award Committee: John G. Bullock, Chair, Northwestern University; Claire L. Adida, University of California, San Diego; Matthew Hayes, Rice University

Recipients: Samara Klar, University of Arizona and Yanna Krupnikov, Stony Brook University

Title: Independent Politics: How American Disdain for Parties Leads to Political Inaction. Cambridge University Press, 2016.

Honorable Mention: Samuel Bowles, Santa Fe Institute

Title: The Moral Economy: Why Good Incentives Are No Substitute for Good Citizens. Yale University Press, 2016.

\section{Best Paper Award}

The Best Paper Award is given to the most outstanding paper in political psychology delivered at the previous year's APSA Annual Meeting.

Award Committee: David J. Hendry, Chair, London School of Economics and Political Science; Cecilia Hyunjung Mo, Vanderbilt University; Mara Ostfeld, University of Michigan

Recipient: Melissa Sands, University of California, Merced

Title: "Who Wants to Tax a Millionaire? Exposure to Inequality Reduces Support for Redistribution."

\section{Best Dissertation Award}

The Best Dissertation Award is given for the best dissertation in political psychology filed during the previous year.
Award Committee: Clayton Nall, Chair, Stanford University; Eun Bin Chung, University of Utah; Sofie Marien, University of Amsterdam and University of Leuven

Recipient: Martin Bisgaard, Aarhus University

Title: "Perceiving the Unobservable."

\section{Distinguished Junior Scholars Award}

The APSA Political Psychology section provides up to five $\$ 400$ grants, meant for travel to the APSA Annual Meeting, for junior scholars (graduate students or those no more than seven years since receiving their $\mathrm{PhD}$ ).

Award Committee: Naomi Levy, Santa Clara University; Efren O. Perez, Vanderbilt University; Claudia Sandoval, Loyola Marymount University

Recipients: Meghan Condon, DePaul University and Tom Jamieson, University of Southern California

\section{SECTION 29. POLITICAL SCIENCE EDUCATION}

Craig L. Brians Award for Excellence in Undergraduate Research and Mentorship

Established in 2014, this award will be awarded annually at the Teaching and Learning Conference, with recognition also given at the APSA annual Political Science Education section reception.

Award Committee: Thomas Ringenberg, Chair, Rockhurst University; Juan Carlos Huerta, Texas A\&M, Corpus Christi; Karen Hult, Virginia Tech University

Recipient: Megan Becker, University of Southern California

\section{The Best APSA Conference Paper Award}

The Best APSA Conference Paper Award is given for the best presentation on undergraduate education at the past year's APSA Annual Meeting.

Award Committee: Bobbi Gentry, Chair, Bridgewater College; Ellen Claes, University of Leuven; J. Cherie Strachan, Central Michigan University

Recipient: Michael T. Rogers, Arkansas Tech University

Title: "The Past, Present, and Possible Future of Civics in Political Science." 
The Distinguished Service Award

Award Committee: Boris Ricks, Chair, California State University, Northridge; Sherri L. Wallace, University of Louisville; Patrick McKinlay, Morningside College; Joseph Roberts, Roger Williams University; Bobby Gentry, Bridgewater College; Terry Gilmour, Midland College; Elizabeth Bennion, Indiana University; Thomas Ringenberg, Rockhurst University; Michael T. Rogers, Arkansas Tech University

Recipient: Michelle D. Deardorff, University of Tennessee, Chattanooga

\section{Lifetime Achievement Award}

The Lifetime Achievement Award is given to a person whose lifetime contribution to political science has had a significant impact on undergraduate education.

Award Committee: Elizabeth Bennion, Chair, Indiana University; Sherri L. Wallace, University of Louisville; Patrick McKinlay, Morningside College; Joseph Roberts, Roger Williams University; Bobby Gentry, Bridgewater College; Terry Gilmour, Midland College; Boris Ricks, California State University, Northridge; Thomas Ringenberg, Rockhurst University; Michael T. Rogers, Arkansas Tech University

Recipient: Dick W. Simpson, University of Illinois at Chicago

\section{SECTION 30. POLITICS, LITERA- TURE, AND FILM}

\section{Wilson Carey McWilliams Best Paper Award}

The Wilson Carey McWilliams Best Paper Award is given for the best paper presented at the previous year's APSA Annual Meeting.

Award Committee: Claudia Franziska Brühwiler, University of St.Gallen, Switzerland; Arlene Saxonhouse, University of Michigan; Lisa Vetter, University of Maryland, Baltimore County

Recipient: Jamie Aroosi, Yeshiva University, New York

Title: "The Future of Human Nature: Rethinking Identity in the 21st Century.”

\section{SECTION 31. FOREIGN POLICY}

\section{Best Paper Award}

This award recognizes the best paper on foreign policy presented at the previous year's APSA Annual Meeting.
Award Committee: Katja Kleinberg, Binghamton University; Danielle Lupton, Colgate University; Dov Levin, Carnegie Mellon University

Recipients: Karen Yarhi-Milo, Princeton University; Joshua Kertzer, Harvard University; Jonathan Renshon, University of Wisconsin

Title: "Tying Hands, Sinking Costs, and Leader Attributes."

\section{Best Book Award}

This award recognizes the best book on foreign policy published in the last two years (2015 or 2016).

Award Committee: Timothy Peterson, University of South Carolina; Joshua Shifrinson, Texas A\&M University

Recipient: Jennifer Erickson, Boston College

Title: Dangerous Trade: Arms Exports, Human Rights, and International Reputation. Columbia University Press, 2015.

Honorable Mention: Sarah Bush, Temple University

Title: The Taming of Democracy Assistance. Cambridge University Press, 2015.

Honorable Mention: Ronald Krebs, University of Minnesota

Title: Narrative and the Making of US National Security. Cambridge University Press, 2015.

\section{SECTION 32. ELECTIONS, PUBLIC} OPINION, AND VOTING BEHAVIOR

\section{Philip E. Converse Best Book Award}

The Philip E. Converse Book Award is given for an outstanding book in the field published at least five years previous.

Award Committee: Andrea Campbell, Chair, Massachusetts Institute of Technology; Shana K. Gadarian, Syracuse University; Jonathan Weiler, University of North Carolina at Chapel Hill

Recipient: Tali Mendelberg, Princeton University

Title: The Race Card: Campaign Strategy, Implicit Messages, and the Norm of Equality. Princeton University Press, 2001.

\section{Emerging Scholar Award}

The Emerging Scholar Award is awarded to the top scholar in the field who is within 10 years of her or his PhD.

Award Committee: Lonna Atkeson, Chair, University of New Mexico; Ernesto Calvo, University of Maryland; Rosalee Clawson, Purdue University
Recipients: Peter K. Enns, Cornell University and Brendan Nyhan, Dartmouth College

\section{Best Paper Award}

The Best Paper Award is given for the best paper delivered at the previous year's APSA Annual Meeting.

Award Committee: Michael Bang Petersen, Chair, Aarhus University; Bonnie Meguid, Rochester University; Kyle Saunders, Colorado State University

Recipients: Thomas Leeper, London School of Economics and Rune Slothuus, Aarhus University

Title: "If Only Citizens Had a Cue: The Process of Opinion Formation over Time."

\section{Best Article in Political Behavior Award}

This award is for the best article published in Political Behavior in the previous calendar year.

Award Committee: David Peterson, Iowa State University; Cecilia Mo, Vanderbilt University; Laura Stephenson, Western Ontario University

Recipients: Alexandra Filindra and Noah J. Kaplan, University of Chicago

Title: "Racial Resentment and Whites' Gun Policy Preference in Contemporary America." Political Behavior 38(2): 255-75.

\section{John Sullivan Award}

The John Sullivan Award for the best paper by a graduate student on a panel sponsored by the APSA Organized Section on Elections, Public Opinion, and Voting Behavior at the previous APSA Annual Meeting. Award Committee: Paul Gronke, Chair, Reed College; Rosario Aguilar, CIDE; Michael Tesler, University of California, Irvine Recipient: John Kane, Stony Brook University

Title: "Are You a Team Player? Party Coalitions, Executives, and Partisan Polarization."

\section{Graduate Student Travel Awards}

Multiple grants are awarded to graduate students who are authors or coauthors of papers on a panel or poster session sponsored by the section at the APSA Annual Meeting.

Award Committee: Jane Green, Cochair, University of Manchester and Neil Malhorta, Cochair, Stanford University Recipients: Carolina Tchintian, Rice University and Enrijeta Shino, University of Florida 
SECTION 34. INTERNATIONAL

HISTORY AND POLITICS

\section{Robert L. Jervis and Paul W. Schroeder Best Book Award}

This award may be granted to a singleauthored or multi-authored book, or to an edited volume. The award will be given to works published in the calendar year prior to the year of the APSA Annual Meeting at which the award is presented. The copyright date of a book will establish the relevant year.

Award Committee: Lise Howard, Georgetown University; Brian Burgoon, University of Amsterdam; Ian Chong, National University of Singapore

Recipient: Rosella Capella Zielinski, Boston University

Title: How Nations Pay for War. Cambridge University Press, 2016.

Honorable Mention: Debra Thompson, Northwestern University

Title: The Schematic State: Race, Transnationalism, and the Politics of the Census. Cambridge University Press, 2016.

\section{Outstanding Article Award in Interna-} tional History and Politics

The Outstanding Article Award in International History and Politics recognizes exceptional peer-reviewed journal articles representing the mission of the International History and Politics Section of the APSA, including innovative work that brings new light to events and processes in international politics, encourages interdisciplinary conversations between political scientists and historians, and advances historiographical methods. The Outstanding Article Award is given to a published article that appeared in print in the calendar year preceding the APSA Annual Meeting at which the award is presented. It may be granted to an article that is single- or coauthored. The year of final journal publication, as detailed by print citation, establishes eligibility.

Award Committee: Daryl Press, Dartmouth College; Fiona Adams, SOAS; Ryan Griffiths, University of Sydney

Recipients: Lisa Blaydes, Stanford University and Christopher Paik, New York University and Abu Dhabi

Title: "The Impact of Holy Land Crusades on State Formation: War Mobilization, Trade Integration, and Political Development on Medieval Europe." International Organization 70 (3): 551-86.

SECTION 35. COMPARATIVE

\section{DEMOCRATIZATION}

\section{Juan Linz Best Dissertation Award}

This award is given for the best dissertation in the comparative study of democracy completed and accepted in the two calendar years immediately prior to the APSA Annual Meeting.

Award Committee: Bryn Rosenfeld, Chair, University of Southern California; Dirk Berg-Schlosser, Universität Marburg; Frances Hagopian, Harvard University Recipient: Avital Livny, University of Illinois

Title: "A State of Distrust: Islamic Mobilization in Turkey and the Muslim World"

HonorableMention:Matthew Henry RhodesPurdy, University of Texas at Austin

Title: "Beyond the Balance Sheet: Performance, Participation, and Regime Support in Latin America."

\section{Best Book Award}

This award is given for the best book in the field of comparative democratization published in 2016 (authored, coauthored, or edited).

Award Committee: Kenneth Roberts, Chair, Cornell University; Jillian Schwedler, Hunter College; Tarek Masoud, Harvard University

Recipients: Steph Haggard, University of California, San Diego and Robert Kaufman, Rutgers University

Title: Dictators and Democrats: Masses, Elites, and Regime Change. Princeton University Press, 2016.

Recipient: Sheena Chestnut Greitens, University of Missouri

Title: Dictators and Their Secret Police: Coercive Institutions and State Violence. Cambridge University Press, 2016.

\section{Best Article Award}

Single-authored or coauthored articles focusing directly on the subject of democratization and published in 2016 are eligible for this award.

Award Committee: Daniel Treisman, Chair, University of California, Los Angeles; Maya Tudor, University of Oxford; Jan Pierskalla, Ohio State University

Recipient: Kurt Weyland, University of Texas at Austin

Title: "Crafting Counterrevolution: How Reactionaries Learned to Combat Change in 1848." American Political Science Review 110(2): 215-31.
Honorable Mention: Ashlea Rundlett, University of Illinois and Milan Svolik, Yale University

Title: "Deliver the Vote! Micromotives and Macrobehavior in Electoral Fraud." American Political Science Review 110(1): 180-97.

\section{Best Field Work Award}

This prize rewards dissertation students who conduct especially innovative and difficult fieldwork. Scholars who are currently writing their dissertations or who complete their dissertations in 2016 are eligible.

Award Committee: Petia Kostadinova, University of Illinois, Chicago; Adrienne LeBas, American University; Mary E. Gallagher, University of Michigan

Recipient: Nicholas Barnes, University of Wisconsin, Madison

Title: "Monopolies of Violence: Gang Governance in Rio de Janeiro."

\section{Best Paper Award}

Given to the best paper on comparative democratization presented at the previous year's APSA Annual Meeting. Papers must be nominated by panel chairs or discussants. Award Committee: Anne Meng, Chair, University of Virginia; Robert Woodberry, Baylor University; Monika Nalepa, University of Chicago

Recipients:Lenka Bustikova, Arizona State University and Cristina Corduneanu-Huci, Central European University

Title: "Patronage, Trust and State Capacity: The Historical Trajectories of Clientelism."

\section{SECTION 36. HUMAN RIGHTS}

\section{Best Book Award}

The best book award recognizes the best book on human rights written by a political scientist and published in the previous two years. Award Committee: Zehra Arat, University of Connecticut; Bethany Barratt, Roosevelt University; Patrice McMahon, University of Nebraska, Lincoln

Recipient: Onur Bakiner, Seattle University Title: Truth Commissions: Memory, Power, and Legitimacy. University of Pennsylvania Press, 2016.

\section{SECTION 37. QUALITATIVE AND MULTI-METHOD RESEARCH}

\section{Giovanni Sartori Book Award}

The Giovanni Sartori Book Award honors Giovanni Sartori's work on qualitative 
methods and concept formation, and especially his contribution to helping scholars think about problems of context as they refine concepts and apply them to new spatial and temporal settings. The award is intended to encompass two types of contributions: new research on methodology per se (i.e., studies that introduce specific methodological innovations or that synthesize and integrate methodological ideas in a way that is in itself a methodological contribution) and substantive work that is an exemplar for the application of qualitative methods.

Award Committee: Hillel Sofer, Chair, Temple University; Harris Mylonas, George Washington University; Ronald R. Krebs, University of Minnesota

Recipient: Katherine J. Cramer, University of Wisconsin, Madison

Title: The Politics of Resentment: Rural Consciousness in Wisconsin and the Rise of Scott Walker. University of Chicago Press, 2016.

\section{Alexander L. George Article-Chapter Award}

The Alexander L. George Article Award honors Alexander George's contributions to the comparative case-study method, including his work linking that method to a systematic concern with research design, and his contribution of developing the idea and the practice of process tracing. This award may be granted to a journal article or to a chapter in an edited volume that stands on its own as an article. The award will be given to an article or book chapter published in the calendar year prior to the year of the APSA Annual Meeting at which the award is presented, with the date of publication being established by the journal issue for articles and the copyright date of the book for chapters.

Award Committee: Bear Braumoeller, Chair, Ohio State University; Laia Balcells, Duke University; Neta Crawford, Boston University

Recipient: Kurt Weyland, University of Texas at Austin

Title: "Crafting Counterrevolution: How Reactionaries Learned to Combat Change in 1848." American Political Science Review 110(2): 215-31.

\section{Sage Paper Award}

The Sage Paper Award honors Sara and George McCune, who founded and sustained Sage Publications as a leading publisher of social science methodology- including very centrally qualitative methods. This award will be given to a paper presented at the previous Annual Meeting of the APSA.

Award Committee: Eva Bellin, Chair, Brandeis University; Janet Lewis, United States Naval Academy; Erica Simmons, University of Wisconsin, Madison

Recipients: Tasha Fairfield, London School of Economics and Andrew Charman, University of California, Berkeley

Title: "Explicit Bayesian Analysis for Process Tracing: Guidelines, Opportunities, and Caveats."

\section{David Collier Mid-Career Achieve- ment Award}

The award honors David Collier's contributions-through his research, graduate teaching, and institution-building-as a founder of the qualitative and multi-method research movement in contemporary political science. The award will be presented annually to a mid-career political scientist to recognize distinction in methodological publications, innovative application of qualitative and multi-method approaches in substantive research, and/or institutional contributions to this area of methodology.

Award Committee: John Gerring, Boston University; Peter Hall, Harvard University; James Mahoney, Northwestern University; Elizabeth Wood, Yale University

Recipients: Tim Büthe, Duke University and Alan Jacobs, University of British Columbia

\section{SECTION 38. SEXUALITY AND} POLITICS

\section{Cynthia Weber Best Conference Paper Award}

The Cynthia Weber Best Conference Paper Award recognizes the best paper exploring sexuality and politics presented at the previous year's APSA Annual Meeting.

Award Committee: Patrick Egan, Chair, New York University; Zein Murib, Fordham University; Erin Mayo-Adam, University of Washington

Recipient: Douglas Page, Gettysburg College Title: "When Do Voters Support the European Union's Involvement in Gay Rights?"

\section{Kenneth Sherrill Best Dissertation Award}

The Best Dissertation Award recognizes the best dissertation on sexuality and politics completed and successfully defended in the previous two calendar years.

Award Committee: Jami Taylor, Chair, University of Toledo; Andrew Reynolds, University of North Carolina at Chapel Hill; Ravi Perry, Virginia Commonwealth University

Recipient: Zein Murib, Fordham University Title: "Brokering Identity: Exploring the Construction of LGBT Political Identity and Interests in US Politics." (PhD dissertation, University of Minnesota).

SECTION 39. HEALTH POLITICS AND POLICY

\section{Leonard S. Robins Best Paper Award}

The Leonard S. Robins Best Paper on Health Politics and Policy Award honors the late Len Robins, who through his presence and gentle questioning at virtually every health politics panel, graciously nurtured the scholarship of both junior and senior scholars.

Award Committee: Miriam Laugesen, Chair, Columbia University; Larry Brown, Columbia University; Jim Morone, Brown University

Recipient: Holly Jarmin, University of Michigan

Title: "Normalizing Tobacco? The Politics of Trade and Tobacco Control."

\section{Health Politics and Policy: Public Engagement Award}

This award recognizes an individual who has been working to improve health and the health care system by actively engaging in politics and policy making. Award Committee: Michael Sparer, Columbia University; Colleen Grogan, University of Chiacgo; Sarah Gollust, University of Minnesota; Bert Rockman, Purdue University Recipient: Drew Altman, Kaiser Family Foundation

\section{SECTION 40. CANADIAN POLITICS}

\section{Mildred A. Schwartz Lifetime Achievement Award}

The Mildred A. Schwartz Lifetime Achievement Award recognizes scholarship and leadership in bringing the study of Canadian Politics to the international political science community.

Award Committee: Melissa Haussman, Chair, Carleton University; John Courtney, 
University of Saskatchewan; Lori Turnbull, Dalhousie University; Angela Wagner, McGill University; Shaun Bowler, University of California, Riverside

Recipient: Richard Johnston, University of British Columbia

\section{Seymour Martin Lipset Best Book Award}

The Seymour Martin Lipset Best Book Award is given to honor a significant contemporary contribution to the scholarship on Canadian politics, Canada in a comparative perspective, or a comparative analysis of Canada with other countries, particularly the United States.

Award Committee: James McCormick, Chair, Iowa State University; Kathy Brock, Queen's University; Sam Fisher, University of South Alabama; David Plazek, Johnson State College; Lori Hausegger, Boise State University

Recipient: Christopher Alcantara, Western University

Title: Negotiating the Deal: Comprehensive Land Claims Agreements in Canada. University of Toronto Press, 2012.

SECTION 41. POLITICAL NETWORKS

\section{Political Ties Award}

This award is given on a biennial basis to the best article published on political networks.

Award Committee: Seth Masket, Chair, University of Denver; Skyler Cranmer, The Ohio State University; Elizabeth Menninga, University of Iowa

Recipients: Jennifer Nicoll Victor, George Mason University and Gregory Koger, University of Miami

Title: "Financing Friends: How Lobbyists Create a Web of Relationships among Members of Congress." Interest Groups $\mathcal{E}$ Advocacy 5 (3): 224-62.

\section{Best Conference Paper Award}

This award is given annually to the best paper on political networks presented by a faculty person delivered at a political science conference in the previous year.

Award Committee: Nick Weller, Chair, University of California, Riverside; Jennifer Larson, New York University; Janet Lewis, United States Naval Academy

Recipients: Cesi Cruz, University of British Columbia; Julien Labonne, University of Oxford; Pablo Querubin, New York University
Title: "Village Social Network Structures and Electoral Competition."

\section{John Sprague Award}

This award is given annually to the best paper on political networks presented by a graduate student delivered at a political science conference in the previous year. There is a fund that supports this award and the award includes a cash award that comes from the fund.

Award Committee: Greg Koger, Chair, University of Miami; Nils Ringe, University of Wisconsin, Madison; Mia Costa, University of Massachusetts Amherst

Recipient: Dror Walter and Sijia Yang, University of Pennsylvania

Title: "Candidates News Coverage and Electoral Success: A Semantic Networks Perspective."

\section{Best Book Award}

The Best Book Award is given on a biennial basis to the best book published on political networks.

Award Committee: John Patty, Chair, University of Chicago; Jennifer Hadden, University of Maryland; Elizabeth Menninga, University of Iowa

Recipient: Navid Hassanpour, Higher School of Economics, Moscow

Title: Leading from the Periphery and Network Collective Action. Cambridge University Press, 2017.

Honorable Mention: Mario Diani, University of Trento

Title: The Cement of Civil Society: Studying Networks in Localities. Cambridge University Press, 2015.

Honorable Mention: Philip Leifeld, University of Glasgow

Title: Policy Debates as Dynamic Networks. Campus Verlag and University of Chicago Press, 2016.

\section{SECTION 42. EXPERIMENTAI RESEARCH}

\section{Best Paper Award}

The Best Paper Award recognizes a paper that was scheduled to be presented at the APSA Annual Meeting and features experimental research.

Award Committee: Jessica Preece, Chair, Brigham Young University; Liz Carlson, Pennsylvania State University; Christian Grose, University of Southern California Recipients: David Doherty, Loyola University Chicago; Conor M. Dowling, University of Mississippi; Michael G. Miller, Barnard College, Columbia University

Title: "The Effects of Candidate Race and Gender on Party Chairs' Assessment of Electoral Viability."

\section{Best Book Award}

The Best Book Award recognizes the best book published in 2016 that either uses or is about experimental research methods in the study of politics.

Award Committee: Emily Beaulieu, Chair, University of Kentucky; Rebecca Morton, New York University; Thad Dunning, University of California, Berkeley

Recipients: Samara Klar, University of Arizona and Yanna Krupnikov, Stony Brook University

Title: Independent Politics: How American Disdain for Parties Leads to Political Inaction. Chicago University Press, 2016.

\section{Best Dissertation Award}

The Best Dissertation Award recognizes the best dissertation completed in calendar year 2016 that utilizes experimental methods on substantive questions about politics or makes a fundamental contribution to experimental methods.

Award Committee: Adam Levine, Chair, Cornell University; Jessica Gottlieb, Texas A\&M University; Dan Nielson, Brigham Young University

Recipient: Alex Coppock, Yale University

Title: "Positive, Small, Homogeneous, and Durable: Political Persuasion in Response to Information."

\section{Public Service Award}

Many experiments only occur thanks to the assistance of non-researchers who provide access to resources and data. This award recognizes a special form of public service, the facilitation of randomized experiments in political science by those outside the academy.

Award Committee: Helen Milner, Chair, Princeton University; Susan Hyde, University of California, Berkeley; Laura Paler, University of Pittsburgh Recipient: Kelly Bidwell, J-PAL

SECTION 43. MIGRATION AND CITIZENSHIP

\section{Best Paper Award}

This award recognizes the best paper on migration and/or citizenship presented at the previous APSA Annual Meeting (either 
as part of a panel or poster session). Award Committee:Linda Bosniak, Chair, Rutgers University, Law School; Phil Triadafilopoulos, University of Toronto; Leila Kawar, University of Massachusetts Amherst Recipients: Charlotte Cavaille, Georgetown University and Jeremy Ferwerda, Dartmouth College

Title: "Understanding the Determinants of Welfare Chauvinism: The Role of Resource Competition."

\section{Best Dissertation Award}

Award for best dissertation on migration and/or citizenship accepted in the previous calendar year.

Award Committee: Kathleen Arnold, Chair DePaul University; Ron Hayduk, San Francisco State University; Anthony M. Messina, Trinity College

Recipient: Adrian J. Shin, University of Michigan

Title: "Primary Resources, Secondary Labor: Natural Resources and Immigration Policy around the World."

\section{Best Article Award}

This award recognizes the best article on migration and/or citizenship accepted in the previous calendar year.

Award Committee: Irene Bloemraad, Chair, University of California, Berkeley; Sara Wallace Goodman, University of California, Irvine; Jay McCann, Purdue University Recipient: Saskia Bonjour, University of Amsterdam
Title: "Speaking of Rights: The Influence of Law and Courts on the Making of Family Migration Policies in Germany." Law $\mathcal{E}$ Policy 38 (4): 328-48.

Honorable Mention: Marc Helbling, University of Bamberg and Richard Traunmüller, University of Mannheim

Title: "How State Support of Religion Shapes Attitudes toward Muslim Immigrants." Comparative Political Studies 49 (3): 391-424.

Honorable Mention: Floris Peters, Maarten Vink, and Hans Schmeets, Maastricht University

Title: "The Ecology of Immigrant Naturalisation: A Life Course Approach in the Context of Institutional Conditions.' Journal of Ethnic and Migration Studies 42(3): 359-81.

\section{Best Book Award}

The Best Book Award recognizes the best book on migration and/or citizenship published in the previous year.

Award Committee: Michael Jones-Correa Chair, University of Pennsylvania; Christine Thurlow Brenner, University of Massachusetts Boston; Erin Aeran Chung, Johns Hopkins University

Recipient: Els de Graauw, Baruch College, CUNY

Title: Making Immigrant Rights Real: Non-Profits and the Politics of Integration in San Francisco. Cornell University Press, 2016.

Recipient: Feliz Garip, Cornell University
Title: On the Move: Changing Mechanisms of Mexico-US Migration. Princeton University Press, 2016.

\section{Best Chapter Award}

This award recognizes the best chapter on migration and/or citizenship published (i.e., printed) in the previous calendar year. Award Committee: David Leal, Chair, University of Texas at Austin; Anna Boucher, University of Sydney; Barbara Buckinx, Princeton University

Recipients: Floris Peters and Maarteen Vink, Maastricht University

Title: "Naturalization and the Socio-Economic Integration of Immigrants: A LifeCourse Perspective," in Handbook on Migration and Social Policy, eds. G. P. Freeman and N. Mirilovic, 362-76. Northampton, MA: Edward Elgar.

SECTION 45. CLASS AND

INEQUALITY

\section{Best Paper Award}

This award recognizes the best paper presented on the topic of economic or social class inequality at the APSA Annual Meeting. Award Committee: Tali Mendelberg, Princeton University and Eleanor Neff Powell, University of Wisconsin, Madison

Recipients: Brian F. Schaffner, Jesse H. Rhodes, and Raymond J. La Raja, University of Massachusetts, Amherst Title: "Understanding Inequality and Representation in Local Politics." 